\title{
Venous and arterial thromboembolic disease in COVID-19
}

\author{
J. ten Berg ${ }^{1,2}(0$ \\ Accepted: 26 June 2021 / Published online: 13 July 2021 \\ (c) The Author(s), under exclusive licence to Springer Science+Business Media, LLC, part of Springer Nature 2021
}

Keywords COVID-19 - Thrombosis · Venous thrombosis · Arterial thrombosis

The severe acute respiratory syndrome (SARS) CoV-2 (the virus that causes COVID-19) infection has led to a pandemic of unprecedented scale. Its disease consequences have to be adequately addressed to prevent further morbidity and mortality. There are recently multiple reports about coagulopathy and disseminated intravascular coagulation (DIC), especially in the sicker COVID-19 patients. Retrospective cohort studies report on increase in D-dimer and fibrin/fibrinogen degradation products; thus, central in this coagulopathy is strong fibrin formation. As compared to bacterial sepsis, in COVID-19, prolongation of prothrombin time, activated partial thromboplastin time, and decrease in antithrombin activity as well as thrombocytopenia is frequently mild. On the other hand, this observed coagulopathy in COVID-19 shows strong similarities with, for example, that of the coronavirus that caused severe acute respiratory syndrome (SARS) in 2002 (SARS-CoV-1) [1]. There are reports that demonstrate higher concentrations of D-dimer and more frequently prolonged prothrombin time in patients admitted to the ICU than in patients that did not need ICU care, and also in patients that died due to COVID-19 than in patients who survived [2-4]. Similarly, Tang et al. report that two-thirds of COVID-19 patients who died had DIC, whereas only $0.6 \%$ of the survivors had DIC [2]. Although severe thrombocytopenia is infrequent in COVID-19, there seems to be an association with a more severe disease state [5]. In summary, these reports demonstrate that coagulopathy in COVID-19 is relevant, since thrombotic complications are prevalent and patients with more severe coagulation abnormalities seem to

J. ten Berg

jurtenberg@gmail.com

1 Department of Cardiology and the St Antonius Center for Platelet Function Research, St Antonius Hospital, Nieuwegein, The Netherlands

2 Cardiovascular Research Institute Maastricht, Maastricht, The Netherlands do worse. The reported high thrombosis incidence is again quite similar as to what is reported with SARS-CoV-1 infection; Chong et al. reported that $20.5 \%$ of patients had deep vein thrombosis, and $11.4 \%$ showed clinical evidence of pulmonary embolism [6]. In contrast, as in SARS-CoV-1, in SARS-CoV-2, bleeding is not frequent, which is different from other RNA viruses that also cause coagulopathy [1, 7]. In this paper, we describe the observed venous and arterial thrombotic complications (venous thromboembolism (VTE), arterial thrombosis and DIC reported in COVID-19 patients.

\section{Venous and arterial thromboembolic disease in COVID-19}

Deep venous thrombosis (DVT) and pulmonary embolism (PE) is frequently reported in patients with COVID-19, incidences depending on the severity of the disease, more prevalent in the sicker patients who need ICU care, as well as the use of routine ultrasound and/or computed tomography imaging [8-10]. The reported incidences seem to be higher than in other (non COVID-19) septic diseased patients [11]. In a recent meta-analysis of 35 observational cohort studies, comprising 9249 patients, the reported incidence of VTE was $18.4 \%$ (95\% confidence interval [CI] 12.0-25.7), of PE $13.5 \%$ (95\% CI 8.4-19.5) and of DVT $11.8 \%$ (95\% CI 7.1-17.4). Also, superficial vein thrombosis and catheterrelated thrombosis are reported frequently. But all organs seem to be vulnerable to venous thrombosis, but this is based on single cases only. Also, for arterial thrombosis, it seems that all organs can be affected; ischemic stroke [9, 12, 13], systemic arterial embolism [9], acute coronary syndrome [12-14], limb and mesenteric ischemia [14, 15] occurring in $1-5 \%$ of COVID-19 patients.

Thrombotic complications in patients with COVID-19 may be due to a higher prevalence of risk factors such as hypertension, hypercholesteremia and atrial fibrillation quite similar to in non-COVID-19 patients. Many observations 
report that patients with COVID-19 who suffered from strokes were older, had more co-morbidities such as hypertension and had higher levels of D-dimer [16]. There may, however, also be more directly COVID-19 related mechanisms of thrombotic disease. First, in situ microvascular thrombosis does occur in the lungs as well as in other organs, and microthrombi are observed in postmortem studies $[17,18]$. Second, as in situ thrombosis in large vessels is very unlikely, many thrombotic large artery occlusions may not be due to atherosclerosis but due to cardioembolism or paradoxical emboli from deep vein thrombosis. In a small retrospective cohort of 32 patients the most prevalent causes of stroke, were cryptogenic stroke and cardioembolism [19]. Also, in a small series of 10 COVID-19 patients suffering from stroke, 5 had occlusions in multiple vascular territories suggesting (paradoxical) embolism as the most likely cause [20]. Further, reports note that many COVID-19 patients with large artery occlusions were younger patients $(<50$ years of age) with low prevalence of atherosclerotic risk factors [21]. Similarly, in a recent report, one third of COVID-19 patients presenting with acute ST-elevation myocardial infarction did not have atherosclerotic obstructive coronary artery disease [22]. Myocardial disfunction, due to myocarditis, systemic inflammation or hypoxemia, among others, may play a role in the development of atrial fibrillation and cardioembolism [23-25].

In conclusion, coagulopathy in COVID-19 is relevant, since thrombotic complications are prevalent and patients with more severe coagulation abnormalities seem to do worse. The reported high thrombosis incidence is very frequent in COVID-19 especially in patients with a more severe disease state. Venous thrombosis occurs more often than arterial thrombosis and all organs seem to be vulnerable to thrombosis. Preliminary reports suggest that paradoxical embolism and cardioembolism play a major role arterial thrombosis in COVID-19 patients.

\section{Declarations}

Ethical approval J.M. ten Berg reports institutional grants from the Netherlands Organization for HealthResearch and Development, a Dutch government institution called ZonMw. J.M. ten Bergreports speaker fees from AstraZeneca, Daiichi Sankyo, Eli Lilly, the Medicines Company,Accumetrics, Boehringer-Ingelheim, Bayer, BMS, Pfizer and Ferrer.

\section{References}

1. Wong RSM, Wu A, To KF, Lee N, Lam CWK, Wong CK, Chan PKS, Ng MHL, Yu LM, Hui DS, Tam JS, Cheng G, Sung JJY (2003) Haematological manifestations in patients with severe acute respiratory syndrome: retrospective analysis. Br Med J 326:1358-1362

2. Tang N, Li D, Wang X, Sun Z (2020) Abnormal coagulation parameters are associated with poor prognosis in patients with novel coronavirus pneumonia. J Thromb Haemost 18:844-847

3. Huang C, Wang Y, Li X, Ren L, Zhao J, Hu Y, Zhang L, Fan G, Xu J, Gu X, Cheng Z, Yu T, Xia J, Wei Y, Wu W, Xie X, Yin W, Li H, Liu M, Xiao Y, Gao H, Guo L, Xie J, Wang G, Jiang R, Gao Z, Jin Q, Wang J, Cao B (2020) Clinical features of patients infected with 2019 novel coronavirus in Wuhan, China. Lancet 395:497-506

4. Zhou F, Yu T, Du R, Fan G, Liu Y, Liu Z, Xiang J, Wang Y, Song B, Gu X, Guan L, Wei Y, Li H, Wu X, Xu J, Tu S, Zhang Y, Chen H, Cao B (2020) Clinical course and risk factors for mortality of adult inpatients with COVID-19 in Wuhan, China: a retrospective cohort study. Lancet 395:1054-1062

5. Lippi G, Plebani M, Henry BM (2020) Thrombocytopenia is associated with severe coronavirus disease 2019 (COVID-19) infections: a meta-analysis. Clin Chim Acta 506:145-148

6. Chong PY, Chui P, Ling AE, Franks TJ, Tai DYH, Leo YS, Kaw GJL, Wansaicheong G, Chan KP, Oon LLE, Teo ES, Tan KB, Nakajima N, Sata T, Travis WD (2004) Analysis of deaths during the Severe Acute Respiratory Syndrome (SARS) epidemic in Singapore: challenges in determining a SARS diagnosis. Arch Pathol Lab Med 128(2):195-204

7. Paessler S, Walker DH (2013) Pathogenesis of the viral hemorrhagic fevers. Annu Rev Pathol Mech Dis 8:411-440

8. Cui S, Chen S, Li X, Liu S, Wang F (2020) Prevalence of venous thromboembolism in patients with severe novel coronavirus pneumonia. J Thromb Haemost 18:1421-1424

9. Klok FA, Kruip MJHA, van der Meer NJM, Arbous MS, Gommers DAMPJ, Kant KM, Kaptein FHJ, van Paassen J, Stals MAM, Huisman MV, Endeman H (2020) Incidence of thrombotic complications in critically ill ICU patients with COVID-19. Thromb Res 191:145-147

10. Poissy J, Goutay J, Caplan M, Parmentier E, Duburcq T, Lassalle F, Jeanpierre E, Rauch A, Labreuche J, Susen S (2020) Pulmonary embolism in patients with COVID-19: awareness of an increased prevalence. Circulation 142:184-186

11. Hanify JM, Dupree LH, Johnson DW, Ferreira JA (2017) Failure of chemical thromboprophylaxis in critically ill medical and surgical patients with sepsis. J Crit Care 37:206-210

12. Lodigiani C, Iapichino G, Carenzo L, Cecconi M, Ferrazzi P, Sebastian T, Kucher N, Studt JD, Sacco C, Alexia B, Sandri MT, Barco S (2020) Venous and arterial thromboembolic complications in COVID-19 patients admitted to an academic hospital in Milan, Italy. Thromb Res 191:9-14

13. Bilaloglu S, Aphinyanaphongs Y, Jones S, Iturrate E, Hochman J, Berger JS (2020) Thrombosis in hospitalized patients with COVID-19 in a New York City health system. JAMA 324:799-801

14. Helms J, Tacquard C, Severac F, Leonard-Lorant I, Ohana M, Delabranche X, Merdji H, Clere-Jehl R, Schenck M, Fagot Gandet F, Fafi-Kremer S, Castelain V, Schneider F, Grunebaum L, Anglés-Cano E, Sattler L, Mertes PM, Meziani F (2020) High risk of thrombosis in patients with severe SARS-CoV-2 infection: a multicenter prospective cohort study. Intensive Care Med 46:1089-1098

15. Fraissé M, Logre E, Pajot O, Mentec H, Plantefève G, Contou D (2020) Thrombotic and hemorrhagic events in critically ill COVID-19 patients: a French monocenter retrospective study. Crit Care. https://doi.org/10.1186/s13054-020-03025-y

16. Qureshi AI, Abd-Allah F, Al-Senani F, Aytac E, Borhani-Haghighi A, Ciccone A, Gomez CR, Gurkas E, Hsu CY, Jani V, Jiao L, Kobayashi A, Lee J, Liaqat J, Mazighi M, Parthasarathy R, Steiner T, Suri MFK, Toyoda K, Ribo M, Gongora-Rivera F, Oliveira-Filho 
J, Uzun G, Wang Y (2020) Management of acute ischemic stroke in patients with COVID-19 infection: report of an international panel. Int J Stroke 15:540-554

17. Varga Z, Flammer AJ, Steiger P, Haberecker M, Andermatt R, Zinkernagel AS, Mehra MR, Schuepbach RA, Ruschitzka F, Moch $\mathrm{H}$ (2020) Endothelial cell infection and endotheliitis in COVID19. Lancet (London, England) 395:1417-1418

18. Lax SF, Skok K, Zechner P, Kessler HH, Kaufmann N, Koelblinger C, Vander K, Bargfrieder U, Trauner M (2020) Pulmonary arterial thrombosis in COVID-19 with fatal outcome: results from a prospective, single-center clinicopathologic case series. Ann Intern Med 173:350-361

19. Yaghi S, Ishida K, Torres J, Mac GB, Raz E, Humbert K, Henninger N, Trivedi T, Lillemoe K, Alam S, Sanger M, Kim S, Scher E, Dehkharghani S, Wachs M, Tanweer O, Volpicelli F, Bosworth B, Lord A, Frontera J (2020) SARS-CoV-2 and stroke in a New York healthcare system. Stroke 51(7):2002-2011

20. Escalard S, Maiër B, Redjem H, Delvoye F, Hébert S, Smajda S, Ciccio G, Desilles JP, Mazighi M, Blanc R, Piotin M (2020) Treatment of acute ischemic stroke due to large vessel occlusion with COVID-19: experience from Paris. Stroke 51:2540-2543

21. Oxley TJ, Mocco J, Majidi S, Kellner CP, Shoirah H, Singh IP, De Leacy RA, Shigematsu T, Ladner TR, Yaeger KA, Skliut M, Weinberger J, Dangayach NS, Bederson JB, Tuhrim S, Fifi JT
(2020) Large-vessel stroke as a presenting feature of Covid-19 in the young. N Engl J Med 382:e60

22. Bangalore S, Sharma A, Slotwiner A, Yatskar L, Harari R, Shah B, Ibrahim H, Friedman GH, Thompson C, Alviar CL, Chadow HL, Fishman GI, Reynolds HR, Keller N, Hochman JS (2020) ST-segment elevation in patients with Covid-19-a case series. N Engl J Med 382:2478-2480

23. Cheng R, Leedy D (2020) COVID-19 and acute myocardial injury: the heart of the matter or an innocent bystander? Heart 106:1122-1124

24. Clerkin KJ, Fried JA, Raikhelkar J, Sayer G, Griffin JM, Masoumi A, Jain SS, Burkhoff D, Kumaraiah D, Rabbani LR, Schwartz A, Uriel N (2020) COVID-19 and cardiovascular disease. Circulation 141:1648-1655

25. Madjid M, Safavi-Naeini P, Solomon SD, Vardeny O (2020) Potential effects of coronaviruses on the cardiovascular system: a review. JAMA Cardiol 5:831-840

Publisher's Note Springer Nature remains neutral with regard to jurisdictional claims in published maps and institutional affiliations. 